\title{
BAHAN KERING DAN BAHAN ORGANIK DAGING AYAM KAMPUNG SUPER YANG DIBERI JERAMI JAGUNG FERMENTASI
}

\section{Evaluation of Dry and Organic Ingredients for Super Kampung Chickens given Fermented Corn Straw}

\author{
${ }^{1}$ Sri Meilan Latabi, ${ }^{* 1}$ Ellen J. Saleh, ${ }^{1}$ Musrifah Nusi, ${ }^{1}$ Sri Suryaningsih Djunu dan ${ }^{2}$ Haris Nur Abdul \\ 1Jurusan Peternakan Fakultas Pertanian Universitas Negeri Gorontalo \\ 2Pengawasan Mutu Pakan Dinas Pertanian Provinsi Gorontalo \\ *Coresponding Authors: email: ellen.saleh@ung.ac.id
}

\begin{abstract}
The purpose of this study was to analyze the dry matter and organic Ingredients of Kampung Super chicken which was given fermented corn straw (JJF) as a substitute for rice bran in the ration. This experimental research used a completely randomized design (CRD), with 5 treatments and 4 replications. The treatment of this research was $\mathrm{P} 0$ (control) $=$ basic ration containing $20 \%$ bran., $\mathrm{P} 1=$ basic ration containing $15 \%$ bran $+5 \%$ JJF., P2 = basic ration containing $10 \%$ bran $+10 \% \mathrm{JJF} ., \mathrm{P} 3=$ basic ration containing $5 \%$ bran $+15 \% \mathrm{JJF}$., $\mathrm{P} 4=$ basic ration contains $20 \% \mathrm{JJF}$. The parameters observed were the dry matter and organic matter content of Kampung Super chicken. Analysis of variance was used for data analysis. The results showed that the addition of JJF did not affect (P> $0.05)$ the dry matter and organic matter content of Kampung Super chicken meat. Fermented corn straw as a substitute for rice bran up to $20 \%$ in the ration does not have a significant effect on dry matter and organic matter of super native chicken meat and can be used as a substitute for bran in the ration.
\end{abstract}

Keywords: Corn Straw, fermented, Super Kampung Chicken Meat, Dry and Organic Ingredients

\begin{abstract}
ABSTRAK
Tujuan penelitian ini adalah menganalisis kandungan bahan kering dan bahan organik ayam kampung Super yang diberi jerami jagung fermentasi (JJF) sebagai pengganti dedak padi dalam ransum. Penelitian eksperimental ini menggunakan Rancangan Acak Lengkap (RAL), dengan 5 perlakuan dan 4 ulangan. Perlakuan penelitian ini adalah P0 (kontrol) = ransum basa yang mengandung dedak 20\% P1 = Ransum dasar yang mengandung dedak 15\% + 5\% JJF. P2 $=$ Ransum dasar yang mengandung 10\% dedak $+10 \%$ JJF. P3 = Ransum dasar yang mengandung dedak $5 \%+$ $15 \%$ JJF. P4 $=$ Ransum dasar mengandung 20\% JJF. Parameter yang diamati adalah bahan kering dan kandungan bahan organik ayam kampung Super. Analisis varian digunakan untuk analisis data. Hasil penelitian menunjukkan bahwa penambahan JJF tidak berpengaruh nyata $(P>0,05)$ terhadap kandungan bahan kering dan bahan organik daging ayam kampung Super. Jerami jagung yang difermentasi sebagai pengganti dedak padi hingga $20 \%$ dalam ransum tidak berpengaruh signifikan terhadap bahan kering dan bahan organik daging ayam kampung super serta dapat digunakan sebagai pengganti dedak dalam ransum.
\end{abstract}

Kata kunci: Jerami Jagung, Daging ayam Kampung Super, Bahan Kering dan Organik, daging Sri Suryaningsih Djunu

Cara Mengutip (APA Citation Style):

Latabi M.S, Saleh J.E, Nusi M., Djunu, S,S., dan Abdul N, H. (2021). Evaluasi Bahan Kering Dan Bahan Organik Daging Ayam Kampung Super Yang Diberi Jerami Jagung Fermentasi. Jambura Journal of Animal Science, 3(2),81-86 


\section{PENDAHULUAN}

Daging ayam adalah bahan pangan yang mengandung nilai nutrisi tinggi dan harga yang relatif murah, sehingga disukai hampir semua orang. Kualitas kimia daging dipengaruhi oleh faktor sebelum dan setelah pemotongan. Faktor sebelum pemotongan yang dapat mempengaruhi kualitas daging adalah genetik, spesies/bangsa, dan bahan aditif (hormon, antibiotik dan mineral) serta keadaan stress, (Soeparno 2009). Salah satu upaya untuk memperbaiki kualitas daging ayam dapat dilakukan dengan modifikasi ransum dengan menggunakan bahan pakan yang dapat memperbaiki kualitas pakan., dan pakan yang digunakan dapat menekan biaya produksi yang tinggi dalam usaha ternak ayam.

Umumnya peternak sering menggunakan bekatul sebagai bahan pakan unggas. Bekatul merupakan bahan penyusun ransum yang popular, akan tetapi dalam penggunaannya bekatul sangat terbatas, tidak tersedia sepanjang waktu. Kandungan nutrisi dalam bekatul yang berkualitas baik adalah protein kasar 9-12 \%, pati 15-35\% lemak 8-12 \% dan serat kasar 8-11 \% (Prambudi, 2007).

Bahan pakan yang dapat menggantikan bekatul dalam ransum ternak ayam, salah satunya jerami jagung. Jerami jagung adalah limbah pertanian tanaman jagung, dapat diberikan pada ternak ruminansia, baik dalam bentuk segar maupun kering atau dalam bentuk olahan wafer (Jamarun, 1991). Kendala limbah pertanian yang digunakan sebagai pakan unggas adalah kualitasnya rendah, kandungan serat kasar yang tinggi. Kendala ini dapat diatasi dengan teknologi fermentasi menggunakan Trichoderma viride.

Fermentasi merupakan proses yang melibatkan aktivitas mikroba dan berlangsung secara anaerob dengan menggunakan substrat tertentu dan menghasilkan suatu produk yang bernilai lebih baik (Mirwandhono dkk., 2006). Fermentasi merombak selulosa dan hemiselulosa sehingga akan menurunkan kadar serat (Djunu, at al, 2021). Beberapa penelitian tentang pakan fermentasi seperti yang dilaporkan oleh Pakaya, $d k k$, (2019) yang menggunakan kulit kakao terfermentasi digunakan sebagai bahan pakan ayam kampung super sebanyak $15 \%$, sedangkan fermentasi jerami jangung menggunakan jamur Trichoderma viride dengan lama inkubasi yang berbeda dilaporkan oleh Usman $d k k$, (2019); Pasue dkk (2019), mamapu meningkatkan kandungan ADF, NDF dan menurunkan kandungan lignin dan hemiselulosa pada jerami jagung. Sigaha $d k k$, (2020); menggunakan pakan termentasi dan pakan tambahan lainnya dalam ransum memberikan pengaruh baik terhadap bobot dan potongan karkas.

Penggunaan jerami jagung yang difermentasi (JJF) terhadap perbaikan kualitas kimia daging daging segar belum banyak terinformasi. Penelitian ini bertujuan untuk menganalisis kandungan bahan kering dan bahan organik daging ayam kampung super yang diberi jerami jagung fermentasi sebagai pengganti bekatul dalam ransum.

\section{METODE PENELITIAN}

Penelitian telah dilaksanakan diLaboratorium ternak unggas Jurusan Peternakan, Universitas Negeri Gorontalo. Metode penelitian yang digunakan adalah metode eksperiment, dengan rancangan Acak Lengkap (RAL) terdiri 5 perlakuan dan 4 ulangan. Jumlah ternak ayam kampung super yang digunakan sebanyak 100 ekor. Perlakuan yang diberikan pada ternak adalah P0 (kontrol) = ransum basa yang mengandung dedak $20 \% \mathrm{P} 1=$ Ransum dasar yang mengandung dedak $15 \%+5 \%$ JJF. P2 = Ransum dasar yang mengandung $10 \%$ dedak $+10 \%$ JJF. P3 = Ransum dasar yang mengandung dedak 5\% $+15 \%$ JJF. P4 $=$ Ransum dasar mengandung 20\% JJF. Pakan basal ayam kampung super disusun sesuai kebutuhan nutrisi ayam kampung super periode starter dan finisher. Pakan dan air minum perlakuan diberikan ad libitium.Susunan pakan basal periode starter dan finisher dapat dilihat pada Tabel 1 dan 2. Untuk fermentasi jagung mengikuti petunjuk Saleh, $d k k$ (2019); Djunu (2015) 
Tabel 1. Komposisi pakan ayam kampung super periode starter umur 0 - 30 Hari

\begin{tabular}{lccccc}
\hline Bahan Pakan 100 \% & P0 & P1 & P2 & P3 & P4 \\
\hline Jagung Kuning & 40 & 40 & 40 & 40 & 40 \\
JJF & 0 & 5 & 10 & 15 & 20 \\
Pakan Komersial & 38 & 38 & 38 & 38 & 38 \\
Bekatul & 20 & 15 & 10 & 5 & 0 \\
Top Mix & 2 & 2 & 2 & 2 & 2 \\
\hline Total & $\mathbf{1 0 0}$ & $\mathbf{1 0 0}$ & $\mathbf{1 0 0}$ & $\mathbf{1 0 0}$ & $\mathbf{1 0 0}$ \\
\hline Kandungan Nutrisi & & & & & \\
Bahan kering (\%) & 87.07 & 87.22 & 87.36 & 87.50 & 87.65 \\
ME (Kkal/kg) & 3009,00 & 2974,75 & 293990 & 2905,34 & 2870,79 \\
Protein Kasar (\%) & 21,52 & 21,62 & 21,72 & 21,82 & 21,92 \\
Serat Kasar (\%) & 4,39 & 4,84 & 5,28 & 5,73 & 6,17 \\
Lemak Kasar $\%)$ & 6,87 & 6,73 & 6,59 & 6,45 & 6,31 \\
Ca (\%) & 0,82 & 0,83 & 0,84 & 0,85 & 0,86 \\
P (\%) & 0,68 & 0,67 & 0,67 & 0,67 & 0,67 \\
\hline Harga & Rp.6.788 & Rp.6.651 & Rp. 6.917 & Rp. 6.981 & Rp.6.755
\end{tabular}

Tabel 2. Komposisi ransum ayam kampung super periode finisher umur 30 hari Finisher

\begin{tabular}{llllll}
\hline Bahan Pakan 100 \% & P0 & P1 & P2 & P3 & P4 \\
\hline Jagung Kuning & 49 & 49 & 49 & 49 & 49 \\
JJF & 0 & 5 & 10 & 15 & 20 \\
Pakan Komersial & 29 & 29 & 29 & 29 & 29 \\
Bekatul & 20 & 15 & 10 & 5 & 0 \\
Top Mix & 2 & 2 & 2 & 2 & 2 \\
\hline Total & $\mathbf{1 0 0}$ & $\mathbf{1 0 0}$ & $\mathbf{1 0 0}$ & $\mathbf{1 0 0}$ & $\mathbf{1 0 0}$ \\
\hline Kandungan Nutrisi & & & & & \\
Bahan Kering (\%) & 86,74 & 86,41 & 86,66 & 86,61 & 86,57 \\
ME(Kkal/kg) & 2832,28 & 2859,18 & 2889,68 & 2918,38 & 2947,08 \\
Protein (\%) & 18,57 & 18,04 & 18,73 & 18,81 & 18,89 \\
Serat Kasar (\%) & 6,28 & 6,91 & 6,62 & 6,79 & 6,96 \\
Lemak (\%) & 4,88 & 4,67 & 4,60 & 4,46 & 4,32 \\
Ca (\%) & 1,37 & 1,37 & 1,39 & 1,40 & 0,92 \\
P (\%) & 0,65 & 0,65 & 0,64 & 0,64 & 0,63 \\
\hline
\end{tabular}

Variabel yang diamati dalam penelitian ini adalah : kandungan bahan organik dan bahan kering daging ayam kampung super.

\section{Penentuan Kadar Bahan Organik}

Penetuan bahan organic daging ayam kampung super dilakukan setelah analisis kadar abu dari dilakukan. Kadar abu dilakukan dengan cara: Sampel dari hasil analisa bahan kering dimasukkan kedalam tanur listrik selama 3 jam pada suhu $60^{\circ} \mathrm{C}$. Tanur dimatikan dan dibiarkan

$$
\begin{aligned}
& \text { Kadar Abu } \quad=\frac{\mathrm{d}-\mathrm{a}}{\mathrm{b}-\mathrm{a}} \times 100 \% \\
& \% \text { Bahan Organik }=\frac{(100 \%-\text { KadarAbu })}{100} \times \mathrm{BK}, \text { atau } \mathrm{BO}=\% \mathrm{BO} \times \mathrm{BK}
\end{aligned}
$$

agak dingin kemudian tanur dibuka, lalu sampel diambil dan dimasukkan kedalam desikator selama 30 menit, kemudian ditimbang (d gram). Penentuan kadar bahan organik total (\%) dihitung berdasarkan prosentase bahan kering daging dikurang dengan kadar abu dari daging.

\section{Analisis data}

Analisis data hasil penelitian digunakan analisis single factor/ANOVA (steel dan Torrie, 1993). 
$\begin{array}{ll}\text { Keterangan: } & \mathrm{a}=\text { Berat cawan kosong (gram) } \\ & \mathrm{b}=\text { Berat cawan }+ \text { sampel sebelum dioven (gram) } \\ \mathrm{d}=\text { Berat cawan }+ \text { sampel setelah ditanur (gram) }\end{array}$

HASIL DAN PEMBAHASAN

Bahan Kering Daging Ayam Kampung Super

Pesentase bahan kering daging ayam kampung super yang diberi pakan yang mengandung jerami jagung yang difermentasi dengan inokulum Trichoderma viride dapat dilihat pada Gambar 1.

Gambar 1. menjelaskan persentase bahan kering daging ayam kampung super yang diberi pakan yang mengandung jerami jagung fermentasi secara angka rataan yaitu P0 (kontrol); P1 (ransum basal + 5\% JJF dari total bekatul); P2 (ransum basal $+10 \%$ JJF dari total bekatul); P3 (ransum basal $+15 \%$ JJF dari total bekatul); P4 (ransum basal + $20 \%$ JJF dari total bekatul), berturut-turut adalah $24,36 \% ; 24,63 \%$; 24,85\%; $24,57 \%$; $25,10 \%$.

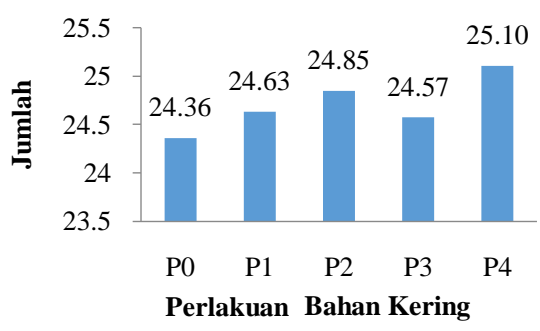

Gambar 1.Grafik Kandungan bahan kering daging ayam kampung super.

Berdasarkan hasil analisis ragam (ANOVA) jerami jagung yang difermentasi menggunakan Trichoderma viride sebagai subtitusi bekatul dalam ransum ayam kampung super, tidak memberikan perbedaan yang nyata atau tidak berpengaruh nyata $(\mathrm{P}>0,05)$ terhadap presentas kandungan bahan kering daging. Dari hasil ini menjelaskan bahwa pemberian JJF sampai dengan taraf $20 \%$ sebagai pengganti bekatul sama dengan menggunakan bekatul. Hal ini sama dengan penyataan Soejono, (1990) bahwa, jerami jagung fermentasi tidak mempengaruhi kandungan total bahan organik dan anorganik. Bahan kering terdapat zat-zat makanan yang diperlukan tubuh baik untuk pertumbuhan maupun untuk reproduksi. Bahan kering terdiri atas senyawa nitrogen, karbohidrat, lemak, vitamin dan mineral (Parakkasi, 2006). Hartadi et al., (1991) menyatakan bahwa, bahan kering terdiri dari bahan organik dan mineral yang dibutuhkan tubuh dalam jumlah cukup untuk pembentukan tulang dan berfungsi sebagai bagian dari enzim dan hormon. Jadi jerami jagung fermentasi tidak mempengaruhi kandungankandungan tesebut hal ini dikarenakan pada saat ayam mengkonsumsi ransum, tingkat palatabilitas dan kandungan gizi dari pakan relatif sama, walaupun terlihat dari konsumsi pakan yang tersisa ditempat pakan adalah jerami jagung fermentasi. Jerami jagung fermentasi berfungsi sebagai sumber serat untuk merangsang gerak peristaltik usus, sehingga pencernaan berjalan dengan sempurna. Menurut pendapat Syamsuddin et al., (2012), bahwa pemberian ransum pada ayam persilangan harus mencukupi kebutuhan nutrisi dan memiliki sifat palatable yang dapat menghasilkan produksi yang tinggi.

Bahan Organik Daging Ayam Kampung Super

Pesentase bahan organik daging ayam kampung super yang diberi pakan yang mengandung jerami jagung yang difermentasi dengan inokulum Trichoderma viride dapat dilihat pada Gambar 2 


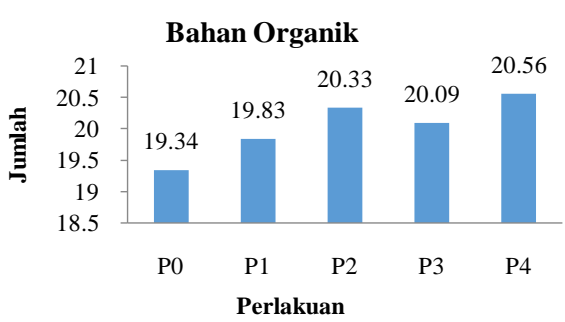

Gambar 2. Bahan kering daging ayam kampung super.

Gambar 2. menjelaskan secara angka rataan persentase bahan organik (BO) daging ayam kampung super yang diberi pakan yang mengandung jerami jagung fermentasi secara angka rataan yaitu P0; P1; P2 ; P3 dan ; P4 adalah 19,34\%; 19,83\%; 20.33\%; 20,09\%; $20,56 \%$. Berdasakan analisis ragam varians ransum ayam kampung super yang mengandung jerami jagung fermentasi tidak memberikan pengaruh yang nyata $(\mathrm{P}>0,05)$ terhadap bahan organik (BO) daging ayam kampung super. Hal ini disebabkan keberadaan BETN sangat tergantung pada komponen lainnya seperti.

\section{DAFTAR PUSTAKA}

Anwar, R., \& Rokhayati, U. A. (2020). Fermentasi Batang Pisang Sepatu (Musa Paradisiaca Forma Typica) Terhadap Palatabilitas Sapi Bali (Bos Sondaicus). Jambura Journal of Animal Science, 3(1), 815.

Saleh, E, J., Suyadi, DJunaidi, I, and Widodo, E, 2019; Nutritive Evaluation of Corn Straw Fermented by Trichoderma Viride as Cross Breed Chicken Feed Stuff in Gorontalo Regency. Int. J. of Adv. Res.7 (Oct).660-666] (ISSN 23205407).www.journalijar.com

Dunggio, A., Datau, F., Dako, S., \& Handayani, S. (2021). Evaluasi Karkas Ayam Kampung Super Yang Diberi Tepung Kunyit (Curcuma domestica val). AgriSains, 22(1), 11-16.

Djunu, S.S., Chuzaemi, S., Djunaidi, H.I., Natsir, H.M., (2021). The Content of Goroho (Musa Acuminafe, Sp) Banana Peels' Fiber Fraction Fermented with Rhizopus Oligosphorus and Trichoderma Viride. Annals of the Romanian Society for Cell Biology, 5394-
Kadar BETN dipengaruhi oleh kadar nutrient lainnya.Untuk kadungan yang termasuk dalam bahan organik adalah serat kasar. Serat kasar adalah bagian dari karbohidrat yang telah dipisahkan dengan BETN (bahan ekstrak tanpa nitrogen) (Hartadi, $d k k, 1991$ ).

\section{KESIMPULAN}

Penggunaan JJF sampai 20 \% sebagai substitusi bekatul menghasilkan kandungan BK dan BO daging ayam kampong super masing-masing berkisar 24,63- 24,85 dan $19,83-20,56 \%$ yang setara dengan tanpa substitusi

5398. Retrieved from http://annalsofrscb.ro/index.php/jour nal/article/view/708

Djunu, S. S. (2015). Penggunaan Dedak Padi Yang Difermentasi Dengan Cairan Rumen Dalam Ransum Terhadap Bobot Hidup, Persentase Karkas dan Lemak Abdominal Ayam Kampung Super. Penelitian Kolaboratif Dana BLU FAPERTA, 1(1924).

Furqaanida, N. 2004. Pemanfaatan Klobot Jagung Sebagai Subtitusi Sumber Serat Ditinjau dari kualitas fisik dan platabilitas wafer ransum komplit untuk domba. Skripsi . Fakultas Peternakan. Institut Pertanian Bogor.

Hartadi, H., Tilman, A. D., Reksohadiprojo, S., Kusumo, S. P dan S. Lebdosoekodjo. 1991. Ilmu Makanan Ternak Dasar. Gadjah Mada University press, Yogyakarta

Takalaw, M.E,. Saleh, J. E., Nusi, M. 2020. Pemanfaatan Jerami Jagung Fermentasi sebagai Pengganti Bekatul dalam Ransum Terhadap Kandungan Serat Kasar dan Bahan Ekstrak Tanpa 
Nitrogen Daging Ayam kampung super. Skripsi. Jurusan Peternakan.Fakultas Pertanian. Universitas Negeri Gorontalo. Bonebolango. Indonesia

Mirwandhono, E., I. Bachari dan D. Situmorang. 2006. Uji nilai nutrisi kulit ubi kayu yang difermentasi dengan Aspergillus niger (nutrient value test of cassava tuber skin fermented by Aspergillus niger). Jurnal Agribisnis Peternakan. 2 (3): 91 - 95.

Pakaya, S. A. (2019). Performa Ayam Kampung Super Yang Di Beri Level Penambahan Tepung Kulit Kakao (Theobroma cacao, L.) Fermentasi Dalam Ransum. Jambura Journal of Animal Science, 1(2), 40-45.

Pasue, I. I. (2019). Analisis Lignin, Selulosa Dan Hemi Selulosa Jerami Jagung Hasil Di Fermentasi Trichoderma Viride Dengan Masa Inkubasi Yang Berbeda. Jambura Journal of Animal Science, 1(2), 62-67.
Sigaha, F., Saleh, E. J., \& Zainudin, S. (2019). Evaluasi persentase karkas ayam kampung super dengan pemberian jermai jagung fermentasi.Jambura Journal of Animal Science, 2(1), 1-7.

Soejono, M. 1990. Petunjuk Laboratorium Analisis dan Evaluasi Pakan. Fakultas Peternakan Universitas Gadjah Mada, Yogyakarta

Syamsuddin, A.R. Mappangaja, dan A. Natsir. 2012. Analisis manfaat program biogas asal ternak bersama masyarakat (BATAMAS) Kota Palopo (Studi Kasus Kelompok Tani Kampulang Kecamatan Wara Selatan Kota Palopo): $18 \mathrm{hlm}$

Usman, N. (2019). Kandungan Acid Detergent Fiber Dan Neutral detergent Fiber Jerami Jagung fermentasi Dengan Mengunakan Jamur Trichoderma Viride Dengan Lama Inkubasi Berbeda.Jambura Journal of Animal Science, 1(2), 57-61 